\title{
Identification of Entomopathogenic Nematode-Associated Bacteria Originating from Mojokerto
}

\author{
Theresia Desy Askitosari*, Tjandra Pantjajani, Stephanie Nathania, Amelia Fedoragnes \\ Wahyudi, Nancy Christina Sugianto
}

Faculty of Biotechnology University of Surabaya, Jln. Raya Kalirungkut, Surabaya 60292, East Java, Indonesia

*Corresponding author: desy_askito@staff.ubaya.ac.id

\section{ABSTRACT}

Entomopathogenic nematodes (EPN) are one of the soil worms that have been widely used as a natural pest control. EPN has its pathogenic capability because of the mutualistic interactions between nematodes and symbiotic bacteria inside the digestive tract of nematodes. Symbiotic bacteria capable of producing exoenzymes that are toxic to insects. The isolation of symbiotic bacteria accomplished by infection of obtained EPN (Belik II isolate) into Tenebrio molitor larvae. Symbiotic bacteria were isolated from the hemolymph of dead larvae on NBTA media. Isolation of symbiotic bacteria was successfully obtained two morphologically distinct bacteria: B 3.1 isolate and B 4 isolate. Both bacteria were further identified using PCR analysis of the 16S rRNA gene. Based on the sequencing results, the B 3.1 isolate was in accordance with Acinetobacter pittii strain ATCC 19004, while B 4 isolate was in accordance with bacteria Enterobacter aerogenes strain KCTC 2190. The characterization of B 3.1 isolate was shown to have similarities with Acinetobacter sp., i.e.: gram-negative, non - motile, rod-shaped, and some other characteristics of biochemical tests. While the characterization of B 4 isolate was shown to have similarities with $E$. aerogenes i.e.: gram-negative, rod-shaped, motile, and some other characteristics of biochemical tests. These findings will be the potential to be applied as biological agents in pest control.

Keywords: Entomopathogenic Nematodes, Symbiotic Bacteria, 16S rRNA gene, Acinetobacter pittii, Enterobacter aerogenes

\section{INTRODUCTION}

Indonesia is the second country in the world after Brazil which is known to have a very large source of biological wealth [1]. This great potential should be utilized to obtain the desired plant products. However, one of the limiting factors in the effort to increase the production of quality food crops is the presence of pests. Losses obtained from pest attacks reach $13 \%$ of total crop production in the world [2].

Currently, various ways have been applied to obtain healthy and quality food crop products. One way is to use biological agents as natural pest control in addition to the use of synthetic insecticides. One example of a biological agent 
that has been widely used today is entomopathogenic nematodes. As the name implies, entomopathogenic nematodes (EPN) can cause disease (pathogenic) to insects. Nematodes of the genus Steinernema and Heterorhabditis are pathogenic nematodes that have very strong virulence against various insects [3]. The pathogenic ability of EPN is the result of mutualistic interactions between nematodes and bacteria in the digestive tract of these nematodes [4]. Xenorhabdus spp. is a bacterium that can have a specific symbiosis with the nematode Steinernema spp. while the bacteria that are symbiotic with the nematodes Heterorhabditis spp. are Photorhabdus spp. $[5,6]$.

However, apart from bacteria make a specific symbiosis with NPS, several other types of bacteria are also associated with NPS. According to Razia et al. [7], even though there are no symbiont bacteria present in the nematodes, the presence of these associated bacteria helps EPN to reproduce and obtain nutrition.

Based on preliminary research conducted by Askitosari [8], it showed that from 27 EPN isolates from soil samples in 13 villages in Trawas, a district in Mojokerto, one of EPN isolates has the potential as a bioinsecticide, namely Belik II. Based on the observations, the EPN Belik II isolate showed the best viability after years of storage in the cold room. Therefore, in this study, the NPS of Belik II isolates were selected to be further identified and characterized. Thus, this study aims to identify and characterize the associated bacteria present in the EPN Belik II isolate. These findings will be fruitful to investigate further the pathogenicity level of the associated bacteria against host insects through the pathogenicity test.

\section{METHODS}

\section{Infection of EPN into Tenebrio molitor}

EPN Belik II isolate was rejuvenated using insect larvae of $T$. molitor to obtain infective juvenile of EPN Belik II isolate. Subsequently, the infective juveniles were reinfected into $T$. molitor (30 larvae) by dropping $1 \mathrm{ml}$ of EPN Belik II infective juvenile suspension (700 JI / $\mathrm{ml}$ ) in a small petri dish coated with wet filter paper. The same treatment was also carried out on the control experiment using $1 \mathrm{ml}$ of sterile distilled water. Petri dishes were incubated at room temperature until all $30 \mathrm{~T}$. molitor larvae died $[9,10]$.

\section{Isolation of EPN-Associated Bacteria from the infected Tenebrio molitor}

The EPN-associated bacteria was isolated by dissecting the dead T. molitor larvae by the EPN invasion symptom test. Symptom test for EPN invasion was observed through the physical characteristics of the dead $T$. molitor cuticle color change (turn into dark color). The $T$. molitor larvae cadavers were sterilized by immersing in $0.6 \% \mathrm{NaOCl}$ solution for a few seconds, followed by 2 minutes. Afterward, the T. molitor larva cadavers were cut in the middle to destroy the intestines. The haemolymph fluid that comes out was dropped on the Nutrient Bromothymol Blue Tetrazolium Chloride Agar (NBTA) by using streak plate method and incubated in dark place, at $27^{\circ} \mathrm{C}$ temperature for 4 days. The grown colonies were then subcultured to obtain secondary cultures on nutrient agar (NA) medium and incubated for 4 days at $27^{\circ} \mathrm{C}$ temperature in the dark place. A single grown colony was then inoculated into nutrient broth (NB) media and placed in a rotary shaker at a speed of $150 \mathrm{rpm}$ at $27^{\circ} \mathrm{C}$ temperature [8]. 


\section{Bacterial Morphological and Biochemical Test}

The isolated bacteria were characterized by growing bacteria on the NBTA agar to observe their shape, edges, elevation, and surface color [11]. The bacterial characterization followed by biochemical test according to the method described in the Bergey's Manual of Systematic Bacteriology. The biochemical tests carried out were catalase test, Sulfide Indol Motility (SIM) test, carbohydrate fermentation test (dextrose, lactose, sucrose), citrate utilization test, Methyl Red-Voges Proskauer test (MR-VP), nitrate reduction test, urease test, amylase test, and gelatinase test.

\section{Genomic DNA Isolation from EPN- Associated Bacteria}

Secondary cultures of isolated EPN-associated bacteria were grown on Luria Bertani (LB) medium and shook overnight at $37^{\circ} \mathrm{C}$. A total of $1.5 \mathrm{ml}$ of culture was centrifuged at $13,000 \mathrm{rpm}$ for 1 minute. The supernatant is removed and repeats the steps until the cell pellets weigh 50$100 \mathrm{mg}$. Pellets were then rinsed with $\mathrm{ddH}_{2} \mathrm{O}$ and subsequently used for Genomic DNA isolation by applying the protocol suggested by ZR Bacterial DNA Miniprep (Zymo Research) manufacture.

\section{Molecular Detection of EPN-Associated Bacteria by using 16S rRNA PCR method EPN-associated bacterial DNA that has been extracted were amplified by applying PCR method using universal primers $16 \mathrm{~S}$ rRNA, i.e. forward primer: 5 'CACGGATCCAGACTTTG ATYMTGGCTCAG 3' and reverse primer: 5 'GTGAAGCTTACGGYTAGCTTGTTACGAC TT 3' (1st Base). The amplicon size of the $16 \mathrm{~S}$ rRNA is approximately $1480 \mathrm{bp}$. Visualization of PCR products was carried out by electrophoresis on $0.8 \%$ agarose gel. Furthermore, the purification of PCR products was carried out using the High Pure PCR}

Product Purification Kit (Roche) and ligated to the pGEM-T Easy (Promega) plasmid DNA (Promega, 2011). Subsequently, the molecular method was followed by the DNA transformation in the competent cells, blue/white colonies screening, recombinant plasmid analysis using PCR, and plamid DNA isolation using the High Pure Plasmid Isolation Kit (Roche).

\section{DNA Sequencing Analysis}

DNA sequences obtained from the sequencing results (Macrogen-South Korea) were compared with the DNA database on NCBI (www.ncbi.nih.nlm.gov) using the BLAST nucleotide. The highest similarity between DNA sequences and the DNA database determined the bacterial species associated with EPN.

\section{RESULTS}

\section{Isolation of EPN-Associated Bacteria}

As shown in Figure 1, the colonies grown in NBTA medium showed round morphology, convex elevation, uneven colony edges, and there is a clear zone surrounding red colony. However, there is a color difference between the two colonies. The colony of B3.1 isolate was red, while the colony of isolate B4 was red accompanied by a faded red color in the middle of the colony.

\section{Morphological and Biochemical Test of EPN- Associated Bacteria}

Based on the result showed in Figure 2, it is known that the two isolated EPN-associated bacteria are both Gram negative rod-shaped bacteria. Furthermore, the recapitulation of the Biochemical test to show the physiological characterization of EPN-associated bacteria is shown in Table 1. 


\section{Molecular Detection of EPN-Associated Bacteria by using 16S rRNA PCR method}

The amplification of 16S rRNA from bacterial genomic DNA was carried out by PCR using $16 \mathrm{~S}$ rRNA universal primers. The amplicon obtained were $~ 1,500$ bp in size (Figure 3 ). This size is in the range of expected amplicon size, which is 1480 bp. Moreover, Figure 4 showed the gel Electrophoresis of extracted-DNA Plasmid $p G E M-T$ containing $16 \mathrm{~S}$ rRNA

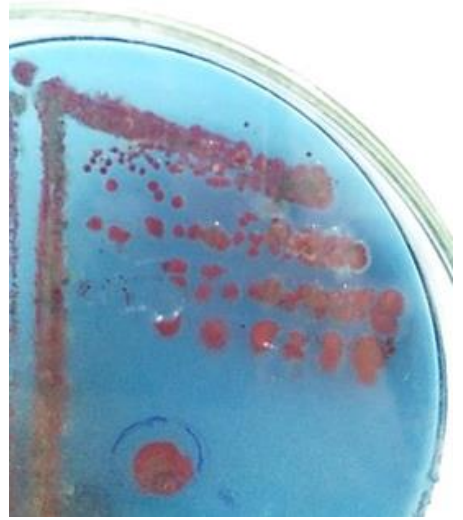

(A) amplicon. Result showed the obtained bands vary in size. The plasmid conformation might affect the speed of movement of the plasmids. Furthermore, based on BLAST sequence analysis, B3.1 isolate showed highest similarity (99 \%) with Acinetobacter pittii strain ATCC 19004, while B4 showed highest similarity (99\%) with Enterobacter aerogenes strain KCTC 2190.

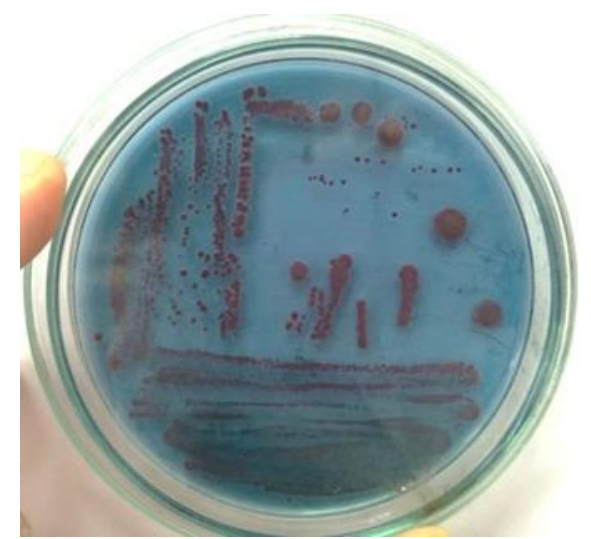

(B)

Figure 1. EPN-associated bacteria isolated from Belik (Mojokerto) soil sample grown in NBTA medium (A: B3.1 isolate, B: B4 isolate)

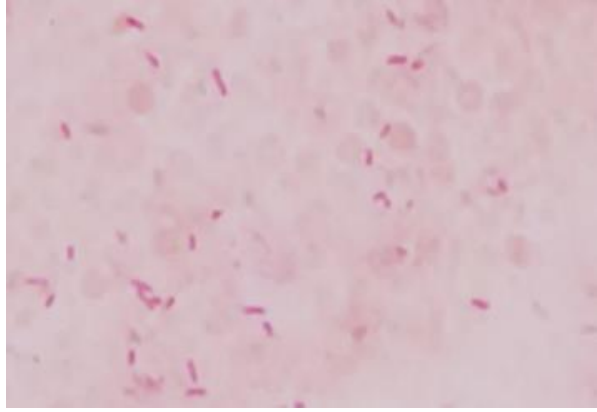

(A)

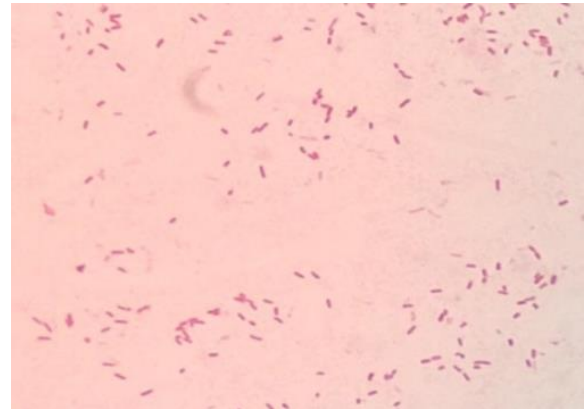

(B)

Figure 2. Gram staining of EPN-associated bacteria isolated from Belik (Mojokerto) soil sample grown in NA medium showed the rod shape observed by microscope (10x100 magnification) (A: B3.1 isoalte, B: B4 isolate) 
Tabel 1. Biochemical Test of EPN-Associated Bacteria Originating from Belik (Mojokerto)

\begin{tabular}{|c|c|c|}
\hline Test & B3.1 & B4 \\
\hline Amylase & + & + \\
\hline Catalase & + & + \\
\hline Nitrate reduction & - & + \\
\hline Gelatinase & - & - \\
\hline Citrate utilization & + & + \\
\hline Indol production & - & - \\
\hline MR & - & - \\
\hline VP & - & - \\
\hline Motility & - & + \\
\hline Urease & - & - \\
\hline Fermentation: & & + \\
\hline Dekstrose & - & + \\
\hline Sukrose & - & - \\
\hline Laktose & - & \\
\hline $\mathrm{H}_{2}$ S production & - & \\
\hline \\
\hline
\end{tabular}

Figure 3. Gel Electrophoresis of PCR 16S rRNA amplification using 16S universal primer (Lane M: $1 \mathrm{~Kb}$ DNA ladder (Hyperladder Bioline); Lane 1: B3.1 isolate, Lane 2: B4 isolate; Lane K- negative control) 


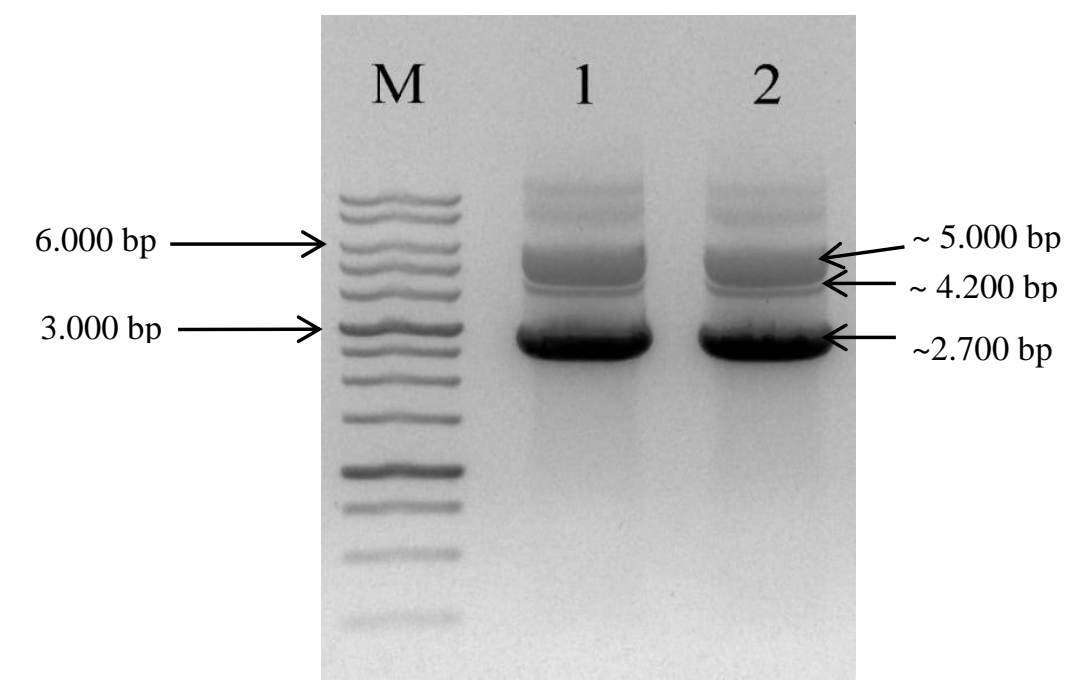

Figure 4. Gel Electrophoresis of extracted-DNA Plasmid $p G E M-T$ containing 16S rRNA amplicon (Lane M: $1 \mathrm{~Kb}$ DNA ladder (Hyperladder Bioline); Lane 1: B3.1, Lane 2: B4)

\section{DISCUSSION}

Based on a preliminary test conducted by Askitosari (2014) [8], it has been reported that EPN Belik II is one of potential candidate for pest control. In this study, it showed EPN Belik II which was reinfected into T. molitor larvae, was able to kill all the 30 larvae population within 60 hours. The isolation of bacteria obtained from T. molitor larvae cadaver was cultivated in NBTA media showed distinctive color between two strains of bacteria. The colony of B3.1 isolate was red (Figure 1A), while the colony of isolate B4 was red with a faded color in the middle of the colony (Figure 1B). The red color is actually produced from the TTC (Tetrazolium Chloride) compound in reduced NBTA media. This compound can be reduced by bacteria with the help of the dehydrogenase enzyme to become a red compound called formazan (1,3,5triphenylformazan) [12].

Based on the gram staining results, it is known that the bacteria obtained are both Gram negative rod-shaped bacteria. In general, most of the bacteria found to be associated with EPN are Gram-negative rod-shape bacteria [13]. Furthermore, based on the molecular detection method (Figure 3\&4), the B3.1 isolate is similar with the Acinetobacter pittii ATCC 19004, while the B4 isolate is similar with Enterobacter aerogenes KCTC 2190 strain. This result was also confirmed by colony morphological observations and biochemical tests carried out (Table 1).

The results of this study indicate the presence of bacteria other than symbiont bacteria (Xenorhabdus spp. and Photorhabdus spp.) which are generally associated with EPN. According to Lysenko \& Weiser (1974) and Gouge \& Snyder (2006), there are several other types of associated bacteria that have been isolated from Steinernema carpocapsase. These bacteria include Alcaligenes sp., Pseudomonas aureofaciens, Pseudomonas fluorescens, Enterobacter agglomerans, Serratia liquefaciens, Acinetobacter sp, and Ochrobactrum sp. In addition, there is a hypothesis that bacteria associated with EPN might be originating from the stomach and cuticle of the EPN $[14,15]$, the stomach of the host insect [16], or it can also be originating from secondary infection.

Although the Acinetobacter pittii and Enterobacter aerogenes strain obtained have been isolated in this study, the pathogenicity 
mechanism of both bacteria is still unclear. However, Enterobacter species are known to produce endotoxins which could be virulence factors of these bacteria [17]. Apart from endotoxins, there is still limited information regarding the potential pathogenicity of Enterobacter species. In addition, there are also opinions regarding the deaths of insect larvae are not actually caused by E. aerogenes. This bacterium is only an opportunistic bacterium that invades larvae after the larvae died. Therefore, E. aerogenes only plays a role in secondary infection [18].

\section{CONCLUSION}

Based on the results of molecular identification, two types of obtained bacteria have high similarity to Acinetobacter pittii strain ATCC 19004 and Enterobacter aerogenes strain KCTC 2190. These results were also supported by the results of biochemical tests which showed match characteristics with the two bacteria. The bacteria found in this study are known as unusual associated bacteria in EPN. Therefore, it is necessary to investigate further the pathogenicity of these bacteria into insects pest, that can be useful to be applied as biological pest control agent.

\section{ACKNOWLEDGEMENT}

Authors would like to thank 'Lembaga Penelitian dan Pengabdian kepada Masyarakat Universitas Surabaya' (LPPM-UBAYA) for the research funding of 'Penelitian Perintis' Scheme.

\section{REFERENCES}

[1] Dibiyantoro, A, L. H. (2005). Pemanfaatan biopestisida untuk mengendalikan OPT bawang merah.
Makalah Pelatihan TOT Pengembangan Teknologi inovatif Bawang Merah. Bandung, Balitsa Lembang.

[2] Bahagiawati. (2001). Manajemen Resistensi Serangga Hama pada Pertanaman Tanaman Transgenik Bt. Buletin AgroBio 4(1), 1-8.

[3] Babic, I., M.F. le Saux, E. Giraud, and N. Boemare. (2000). Occurence of natural dixenic associations between the symbiont Photorhabdus luminescens and bacteria related to Ochrobactrum spp. in tropical entomopathogenic Heterorhabditis spp. (Nematoda, Rhabditida). Microbiology 146:709-718.

[4] Akhdiya, A., Pratiwi, E., Samudra, I. M., \& Priatno, T. P. (2008). Toksisitas Bakteri Simbion Nematoda Patogen Serangga terhadap Larva Ulat Hongkong. Penelitian Pertanian Tanaman Pangan Vol. 27 No. 2, 120-125.

[5] Forst, S. and D. Clarke. (2002). Bacterianematode symbioses, p. 57-77. In R. Gaugler(ed.), Entomopathogenic nematology. CABI Publishing, Wallingford, United Kingdom.

[6] Forst, S., Dowds, B., Boemare, N., and Stackebrandt, E. (1997). Xenorhabdus and Photorhabdus spp.: bugs that kill bugs. Annu. Rev. Microbiol. 51, 47-72.

[7] Razia, P., Karthik Raja, R., Padmanaban, K., Chellapandi, P., \& Sivaramakrishnan, S. (2011). 16S rDNA-Based Phylogeny of Non-Symbiotic Bacteria of Entomopathogenic Nematodes from Infected Insect Cadavers. Genomics Proteomics Bioinformatics Vol. 9 No. 3, 104-112.

[8] Askitosari, T.D. (2014). Ekstraksi Eksotoksin Bakteri Simbion Nematoda Patogen Serangga Hasil Isolasi Sampel Tanah Trawas, Mojokerto. Biotechnological Approaches to Blue 
Economy Implementation (hal. 216-222). Surabaya: Ubaya Press.

[9] Wiratno, \& Rohimatun. (2012). Patogenisitas Nematoda Heterorhabditis sp. terhadap Kumbang Daun Kelapa Brontispa longissima Gestro. Jurnal Littri Vol.18 No. 4, 137-142.

[10] Djamilah, Priyatiningsih, \& Widiarto, S. (2011). Patogenisitas Steinernema sp. Isolat Bengkulu Terhadap Rayap (Coptotermes curvignathus Holmgren). Manggaro Vol.12 No.1, 39-43.

[11] Cappuccino G .James, Sherman Natalie. (2005). Microbiology A laboratory manual. 7th ed. Pearson/Benjamin Cummings, San Francisco, CA.

[12] Yuniarti, E., \& Saraswati, R. (2007). Aktivitas Dehidrogenase. In E. Husen, R. Saraswati, \& R. D. Simanungkalit, Metode Analisis Biologi Tanah (pp. 150153). Balai Besar Litbang Sumberdaya Lahan Pertanian Badan Penelitian dan Pengembangan Pertanian Departemen Pertanian.

[13] Akhrust R.J. (1980). Morphological and Functional Dimorphism in Xenorhabdus spp., Bacteria Symbiotically Associated with the Insect Pathogenic Nematodes Neoaplectana and Heterorhabditis. J. General Microbiology, 121: 303-309.
[14] Bonifassi, A., Fischer-Le Saux, M., Boemare, N., Lanois, A., Laumond, C., Smart, G., 1999. Gnotobiological study of infective juveniles and symbionts of Steinernema scapterisci: a model to clarify the concept of the natural occurrence of monoxenic associations in entomopathogenic nematodes. J. Invertebr. Pathol. 74, 164-172.

[15] Isaacson, P.J., Webster, J.M., 2002. Antimicrobial activity of Xenorhabdus sp. RIO (Enterobacteriaceae) symbiont of the entomopathogenic nematode, Steinernema riobrave (Rhabditida: Steinernematidae). J. Invertebr. Pathol. 79, 146-153.

[16] Bucher, G.E., Williams, R., 1967. The microbial flora of laboratory cultures of the greater wax moth and its effect on rearing parasites. J. Invertebr. Pathol. 9, 464-473.

[17] Bone, R. C. 1993. Gram-negative sepsis: a dilemma of modern medicine. Clin. Microbiol. Rev. 6:57-68.

[18] Bulla, L. A., Rhodes, R. A., \& Julian, G. S. (1975). Annual Review of Microbiology. California: Palo Alto. 